\title{
On the Breeding of Bivoltine Breeds of the Silkworm, Bombyx mori L. (Lepidoptera: Bombycidae), Tolerant to High Temperature and High Humidity Conditions of the Tropics
}

\author{
Harjeet Singh $^{1}$ and N. Suresh Kumar ${ }^{2}$ \\ ${ }^{1}$ Government Degree College, Pehil Haveli, Poonch, Jammu \& Kashmir, India \\ ${ }^{2}$ Central Sericultural Research and Training institute, Central Silk Board, Berhampore 742101, India
}

Correspondence should be addressed to N. Suresh Kumar, nairsuresh_in@yahoo.com

Received 14 May 2010; Accepted 10 June 2010

Academic Editor: Subba Reddy Palli

Copyright $\odot 2010$ H. Singh and N. S. Kumar. This is an open access article distributed under the Creative Commons Attribution License, which permits unrestricted use, distribution, and reproduction in any medium, provided the original work is properly cited.

\begin{abstract}
The hot climatic conditions of tropics prevailing particularly in summer are contributing to the poor performance of the bivoltine breeds and the most important aspect is that many quantitative characters such as viability and cocoon traits decline sharply when temperature is high. Hence, in a tropical country like India, it is very essential to develop bivoltine breeds/hybrids which can withstand the high temperature stress conditions. This has resulted in the development of CSR18 $\times$ CSR19, compatible hybrid for rearing throughout the year by utilizing Japanese thermotolerant hybrids as breeding resource material. Though, the introduction of CSR18 $\times$ CSR19 in the field during summer months had considerable impact, the productivity level and returns realized do not match that of other productive CSR hybrids. Therefore, the acceptance level of this hybrid with the farmers was not up to the expected level. This has necessitated the development of a temperature tolerant hybrid with better productivity traits than CSR18 $\times$ CSR19. Though, it was a difficult task to break the negative correlation associated with survival and productivity traits, attempts on this line had resulted in the development of CSR46 $\times$ CSR47, a temperature tolerant bivoltine hybrid with better productivity traits than CSR $18 \times$ CSR19. However, though, these hybrids are tolerant to high temperature environments, they are not tolerant to many of the silkworm diseases. Keeping this in view, an attempt is made to develop silkworm hybrids tolerant to high temperature environments.
\end{abstract}

\section{Introduction}

Silkworm breeding aims to achieve superior performances in respect of egg yield, cocoon raw silk yield, cocoon stability, and production followed by expansion to new areas besides others. Silkworm breeders continue to strive for an inherent gain in resistance by incorporating resistant genes into the genetic backgrounds of high yielding temperate bivoltines. Besides this, the cocoon crop stability also relies more on improving other production technologies which have to be explored. It is interesting to note that in inbreeding experiments, besides choice of parents, selection and inbreeding the hybrids are very important which have to be carefully executed since both inbreeding and hybridization are forms of nonrandom mating or selective mating, but operate in opposite ways. Inbreeding is a kind of genetic assortative mating as compared with phenotypic assortative mating in hybridization. The major effect of inbreeding which is most apparent in the reduction of mean performance of the population is in question. While gene frequencies do not change on the whole, genotypic frequencies do change towards the production of more homozygotes and fewer hetrozygotes. Thus, any change in the population mean as a result of inbreeding must be related to difference in genotype value between homozygote and heterozygote [1].

India enjoys the patronage of second position for the production of silk in the world next only to China. Sericulture in India is practiced predominantly in tropical environmental regions such as Karnataka, Tamil Nadu, Andhra Pradesh and West Bengal and to a limited extent in temperate environment of Jammu and Kashmir. The existing tropical situation provides scope for exploiting multivoltine 
$\times$ bivoltine hybrid at commercial venture as they are hardy and have tremendous ability to survive and reproduce under varied or fluctuating environmental climatic conditions. But its quality is at low ebb when compared to the existing international standard.

Considering these drawbacks, adoption of bivoltine sericulture became imperative and imminent considering its potentiality even under Indian tropical conditions. Keeping this in view, breeding experiments were initiated at Central Sericultural Research and Training Institute, Mysore to evolve hardy bivoltine silkworm races suited to tropical conditions for achieving the primary objective of establishing bivoltine hybrids as a concept among sericulturists. Accordingly, many productive and qualitatively superior bivoltine hybrids have been developed by utilizing Japanese commercial hybrids as breeding resource material [2]. However, the hot climatic conditions prevailing particularly in summer are not conducive to rear these high yielding bivoltine hybrids throughout the year. It is as well-established fact that under tropical condition, unlike polyvoltines, bivoltines are more vulnerable to various stresses, that is, hot climatic conditions of tropics, poor leaf quality, and improper management during summer which are not conducive for bivoltine rearing. In order to select efficiently the breeds with high temperature tolerance, it is important to analyse the impact of high temperature on many silk yielding attributes of silkworm races and their heritability.

The success of sericulture industry depends upon several factors of which the impact of the environmental factors such as biotic and abiotic factors is of vital importance. Among the abiotic factors, temperature plays a major role on growth and productivity of silkworm, as it is a poikilothermic (cold blooded) insect [3]. It is also known that the late age silkworms prefer relatively lower temperature than young age and fluctuation of temperature during different stages of larval development was found to be more favourable for growth and development of larvae than constant temperature. There are ample literature stating that good quality cocoons are produced within a temperature range of $22-27^{\circ} \mathrm{C}$ and above these levels makes the cocoon quality poorer [4]. However, polyvoltine races reared in tropical countries are known to tolerate slightly higher temperature [5], which is also true with crossbreeds, that have been evolved specially for tropical climate.

The continued efforts for the improvement of cocoon characters of domesticated silkworm were aimed at increased quality silk production. The main objective of silkworm rearing is to produce qualitatively and quantitatively superior cocoons, which in turn will have a direct bearing on the raw silk production. Therefore, it becomes imperative or essential to develop bivoltine breeds/hybrids which can with stand high temperature stress conditions. Sericulture, the viable agro-based industry aptly matches the socioeconomic backdrop of rural India. One of the main aims of the breeders is to recommend silkworm breeds/hybrids to farmers that are stable under different environmental conditions and minimize the risk of falling below a certain yield level. Silkworm breeds that are reared over a series of environment exhibiting less variation are considered stable. The climatic
TABle 1

\begin{tabular}{llll}
\hline Sl. No. & $\begin{array}{c}\text { Breeding } \\
\text { lines }\end{array}$ & Parentage & Breeding Plan \\
\hline & \multicolumn{3}{c}{ Dumbbell } \\
\hline 1 & HH8 & CSR19, & $($ CSR47 $\times$ CSR19 $) \times$ CSR51 \\
2 & HH10 & CSR47, & $($ CSR51 $\times$ CSR19 $) \times$ CSR51 \\
3 & HH12 & CSR51. & $($ CSR51 $\times$ CSR47 $) \times$ CSR51 \\
\hline
\end{tabular}

conditions prevailing in the tropics are most unpredictable and the problems of tropical sericulture are occurrence of aggravated silkworm diseases, unsuitable mulberry leaf for bivoltine silkworms, and lack of sustainable silkworm breeds for effective selection of desirable characters. In order to introduce bivoltine races in a tropical country like India, it is necessary to have stability in cocoon crop under high temperature environment. The prerequisite of summer hybrid is healthiness and adaptability to adverse conditions of high temperature, low food quality, relatively higher economic traits, with potential for increased cocoon production. Considering the poor performance of productive bivoltine hybrids during summer season, emphasis was given to evolve bivoltine silkworm breeds suitable to tropical conditions for achieving the primary objective of establishing bivoltine sericulture with quality raw silk among sericulturists. Thus a compatible robust bivoltine hybrid, CSR18 $\times$ CSR 19 was evolved from a Japanese hybrid, B201 × BCS12 under high temperature $\left(36 \pm 1^{\circ} \mathrm{C}\right)$ and high humidity $(85 \pm 5 \%)$ conditions $[6,7]$ by taking clues from earlier experiments conducted by Japanese experts [8-10]. Though, this hybrid was authorized by Central Silk Board for commercialization, large-scale testing in the field is yet to take momentum due to its low productivity. Therefore, attempts are being made to develop bivoltine hybrids tolerant to high temperature conditions.

\section{Materials and Methods}

To initiate the breeding programme of high temperature $\left(40 \pm 1^{\circ} \mathrm{C}\right)$ and high humidity $(85 \pm 5 \%)$, six bivoltine breeds three each of oval, namely, CSR18, CSR46, and CSR50 and dumbbell, namely, CSR19, CSR47, and CSR51 were found to be temperature tolerant and selected as parental breeds for breeding programme. In oval lines, CSR46 and CSR50 are characterized by plain larvae while CSR18 is characterized by marked and plain (sex limited) larvae where female is marked and male is plain, similarly in dumbbell lines, CSR19 is characterized by sex limited (marked and plain) larvae and CSR47 and CSR51 are characterized by marked larvae.

For the development of breeds through appropriate techniques breeding programme was initiated with an objective to introduce the bivoltine breeds/hybrids for high temperature, that is, $40 \pm 1^{\circ} \mathrm{C}$ and high relative humidity, that is, $85 \pm 5 \%$. By utilising the breeding resource material three dumbbell lines, namely, $\mathrm{HH} 8, \mathrm{HH} 10, \mathrm{HH} 12$, tolerant to high temperature and high humidity conditions were developed, the parentage of which are depicted in Table 1. 
Silkworm rearing was conducted following the standard method under the recommended temperature and relative humidity till 2nd day of 5th instar. During the process of breeding composite layings were prepared by utilized fifteen to twenty disease-free layings to ensure large population size with wide genetic base from F1 to F5, and progenies were raised by conducted mass rearing. Ten replicates of 100 larvae were counted after passing out 3 rd moult and were kept in plastic trays and subjected for two different temperature treatments, that is, $40 \pm 1{ }^{\circ} \mathrm{C}$ and $50 \pm 5 \% \mathrm{RH}$ and $40 \pm 1{ }^{\circ} \mathrm{C}$ and $85 \pm 5 \% \mathrm{RH}$ in SERICATRON. (Environmental chamber with precise and automatic control facilities for uniform maintenance of temperature and humidity) from 3rd day of 5 th instar and were fed fresh mulberry leaves twice a day. From F1 to F5 continuously thermal exposure was given, the larvae selected for two different high temperature treatments were exposed six hours per day (10 AM to $4 \mathrm{PM}$ ) till spinning which is appropriate time for exposure to high temperature [7-9]. As continuous exposure under high temperature conditions reduces quantitative traits drastically, recurrent backcrossing/outcrossing was given with one of the productive parental breeds as outlined in each breeding plan. From the base population of F1, larvae were also counted (300 larvae) and inbreeding was done for each breed and reared at room temperature up to F12, these room temperature reared batches were considered as control batches.

Cellular rearing was resorted to from F6 onwards to F12 with minimum five replications preceded by half sib/full sib mating for three different temperatures. At the time of brushing, the rich egg layings showing good hatching \% were selected from each set of room temperature and two different high temperatures and reared. Owing the thermal effect in successive generations, it was observed that after 5th generation both qualitative and quantative characters have declined sharply. So the experiment was modified in such a way that with every alternate generation from F6 onwards to F12 both high temperature lines were brought to room temperature conditions and reared continuously till spinning to recoup the lost vitality under stress conditions. The breeding plans of the three dumbbell lines are depicted in Figures 1 to 3.

\section{Results}

\subsection{Performance of HH8 at Two Temperature Conditions}

3.1.1. Rearing Performance. Generation wise mean performance for rearing of $\mathrm{HH} 8$ is presented in Table 2. Highest fecundity (598) was recorded at F6 and lowest (544) was recorded at $\mathrm{F} 8$ at $40 \pm 1{ }^{\circ} \mathrm{C}$ and $50 \pm 5 \%$ RH. At $40 \pm 1{ }^{\circ} \mathrm{C}$ and $50 \pm 5 \% \mathrm{RH}$, the $V$ age larval duration ranged from 132 to 138 hours with the shortest of 132 being recorded at F4, F7, and F11. However, at $25 \pm 1{ }^{\circ} \mathrm{C}$ and $65 \pm 5 \% \mathrm{RH}$ shortest $V$ age larval span of $138 \mathrm{hrs}$ was observed at $\mathrm{F} 7$ and it ranged from $138 \mathrm{hrs}$ to $150 \mathrm{hrs}$ (F5). The survival percentage in respect of $\mathrm{HH} 8$ at $40 \pm 1^{\circ} \mathrm{C}$ and $85 \pm 5 \% \mathrm{RH}$ ranged from 76.3 to $89.3 \%$ with the highest of $89.3 \%$ recorded at $\mathrm{F} 3$ and the lowest of $76.3 \%$ at F5. However, at $25 \pm 1{ }^{\circ} \mathrm{C}$ and $65 \pm 5 \%$
RH the survival percentage ranged from 90.9 to $94.1 \%$ with the highest of $94.1 \%$ at $\mathrm{F} 1$ and the lowest of $90.9 \%$ recorded at F6. At $40 \pm 1{ }^{\circ} \mathrm{C}$ and $85 \pm 5 \% \mathrm{RH}$, the highest cocoon yield/10000 larvae for HH8 was observed in F9 $(15.79 \mathrm{~kg})$ and the least $(14.37 \mathrm{~kg})$ at F2. Similarly, at $25 \pm 1^{\circ} \mathrm{C}$ and $65 \pm$ $5 \% \mathrm{RH}$, the highest for HH8 was observed in F6 (18.58 kg) and the least $(17.23 \mathrm{~kg})$ at $\mathrm{F} 2$. The highest cocoon weight $(1.607 \mathrm{~g})$ for $\mathrm{HH} 8$ was recorded at $40 \pm 1^{\circ} \mathrm{C}$ and $85 \pm 5 \% \mathrm{RH}$ in F7 and the lowest $(1.562 \mathrm{~g})$ at F7. Similarly, at $25 \pm 1{ }^{\circ} \mathrm{C}$ and $65 \pm 5 \% \mathrm{RH}$, the highest for $\mathrm{HH} 3$ was observed in F5 (1.904 g) and the lowest $(1.727 \mathrm{~g})$ in F3. The highest cocoon shell weight at $40 \pm 1{ }^{\circ} \mathrm{C}$ and $85 \pm 5 \% \mathrm{RH}$ for HH8 was observed in F9 $(0.342 \mathrm{~g})$ and the lowest $(0.316 \mathrm{~g})$ in F2. Similarly, at $25 \pm 1{ }^{\circ} \mathrm{C}$ and $65 \pm 5 \% \mathrm{RH}$, the highest for HH8 was observed in F5 $(0.440 \mathrm{~g})$ and the lowest $(0.379 \mathrm{~g})$ in F3. The highest cocoon shell percentage at $40 \pm 1^{\circ} \mathrm{C}$ and $85 \pm 5 \% \mathrm{RH}$ for HH8 was observed in F9 (21.42\%) and the lowest (20.26\%) in F2. Similarly, at $25 \pm 1{ }^{\circ} \mathrm{C}$ and $65 \pm 5 \% \mathrm{RH}$, the highest for HH8 was observed in F2 (22.78\%) and the lowest (22.19) in F1. Analysis of variance with regard to pupation rate recorded highly significant difference $(P>.001)$ while Yield/10000 larvae recorded significant difference $(P>.01)$ and fecundity recorded significant difference $(P>.05)$ at $40 \pm 1{ }^{\circ} \mathrm{C}$ and $85 \pm 5 \% \mathrm{RH}$ between generations. Similarly, at $25 \pm 1^{\circ} \mathrm{C}$ and $65 \pm 5 \% \mathrm{RH}$, cocoon weight, shell weight recorded highly significant difference $(P>.01)$ and Yield/10000 larvae recorded significant difference $(P>.05)$ (Table 2$)$.

3.1.2. Reeling Performance. Generation wise mean performance for reeling of $\mathrm{HH} 8$ is presented in Table 3. The reelability at $40 \pm 1^{\circ} \mathrm{C}$ and $85 \pm 5 \% \mathrm{RH}$ ranged from $80 \%$ (F3) to $82 \%$ (F1 and F2). Similarly, at $25 \pm 1{ }^{\circ} \mathrm{C}$ and $65 \pm 5 \% \mathrm{RH}$, it ranged from $84.67 \%$ at $\mathrm{F} 2$ to $86.67 \%$ at F3 and F12. Longest filament length of $997 \mathrm{~m}$ was recorded at $\mathrm{F} 1$ and the least of $851 \mathrm{~m}$ in $\mathrm{F} 3$ at $40 \pm 1^{\circ} \mathrm{C}$ and $50 \pm 5 \% \mathrm{RH}$. However, at $25 \pm 1^{\circ} \mathrm{C}$ and $65 \pm 5 \% \mathrm{RH}$, the longest of $1106 \mathrm{~m}$ was recorded in F10 and least of $980 \mathrm{~m}$ in F2. Lowest renditta of 6.38 was observed at $\mathrm{F} 9$ and it ranged from 6.38 to $6.79(\mathrm{~F} 2)$ at $40 \pm 1^{\circ} \mathrm{C}$ and $85 \pm 5 \% \mathrm{RH}$. However, at $25 \pm 1^{\circ} \mathrm{C}$ and $65 \pm 5 \% \mathrm{RH}$, it ranged from $5.47(\mathrm{~F} 4)$ to $5.72(\mathrm{~F} 1)$. The highest raw silk percentage at $40 \pm 1^{\circ} \mathrm{C}$ and $85 \pm 5 \% \mathrm{RH}$ was recorded in $\mathrm{F9}(15.69 \%)$ and the lowest (14.76\%) in F2. Similarly, at $25 \pm 1^{\circ} \mathrm{C}$ and $65 \pm 5 \%$ $\mathrm{RH}$, the highest was observed in $\mathrm{F} 4(18.27 \%)$ and the lowest $(17.48 \%)$ in F1. Thinner filament size of 2.29 was observed at $\mathrm{F} 3$ and it ranged from 2.29 to $2.50 \mathrm{~d}(\mathrm{~F} 4)$ at $40 \pm 1{ }^{\circ} \mathrm{C}$ and $85 \pm 5 \%$ RH. Similarly, at $25 \pm 11^{\circ} \mathrm{C}$ and $65 \pm 5 \% \mathrm{RH}$, it ranged from $2.51 \mathrm{~d}(\mathrm{~F} 2)$ to $3 \mathrm{~d}(\mathrm{~F} 4)$. Highest neatness at $40 \pm 1^{\circ} \mathrm{C}$ and $85 \pm 5 \%$ RH was observed in F7 (90.67 p) and the lowest (85.0 p) in (F1). Similarly, at $25 \pm 1{ }^{\circ} \mathrm{C}$ and $65 \pm 5 \% \mathrm{RH}$, the highest was observed in F4 (92.67 p) and the lowest (90.67 p) in F5. Analysis of variance with regard to filament length $(\mathrm{m})$, filament size (d) recorded highly significant difference $(P>.001)$ while reelability recorded significant difference $(P>.01)$ at $40 \pm 1^{\circ} \mathrm{C}$ and $85 \pm 5 \% \mathrm{RH}$ between generations. Similarly, at $25 \pm 1^{\circ} \mathrm{C}$ and $65 \pm 5 \% \mathrm{RH}$, filament length (m) and filament size (d) recorded highly significant difference $(P>.001)$ and reelability recorded significant difference $(P>.01)$ was recorded (Table 3$)$. 


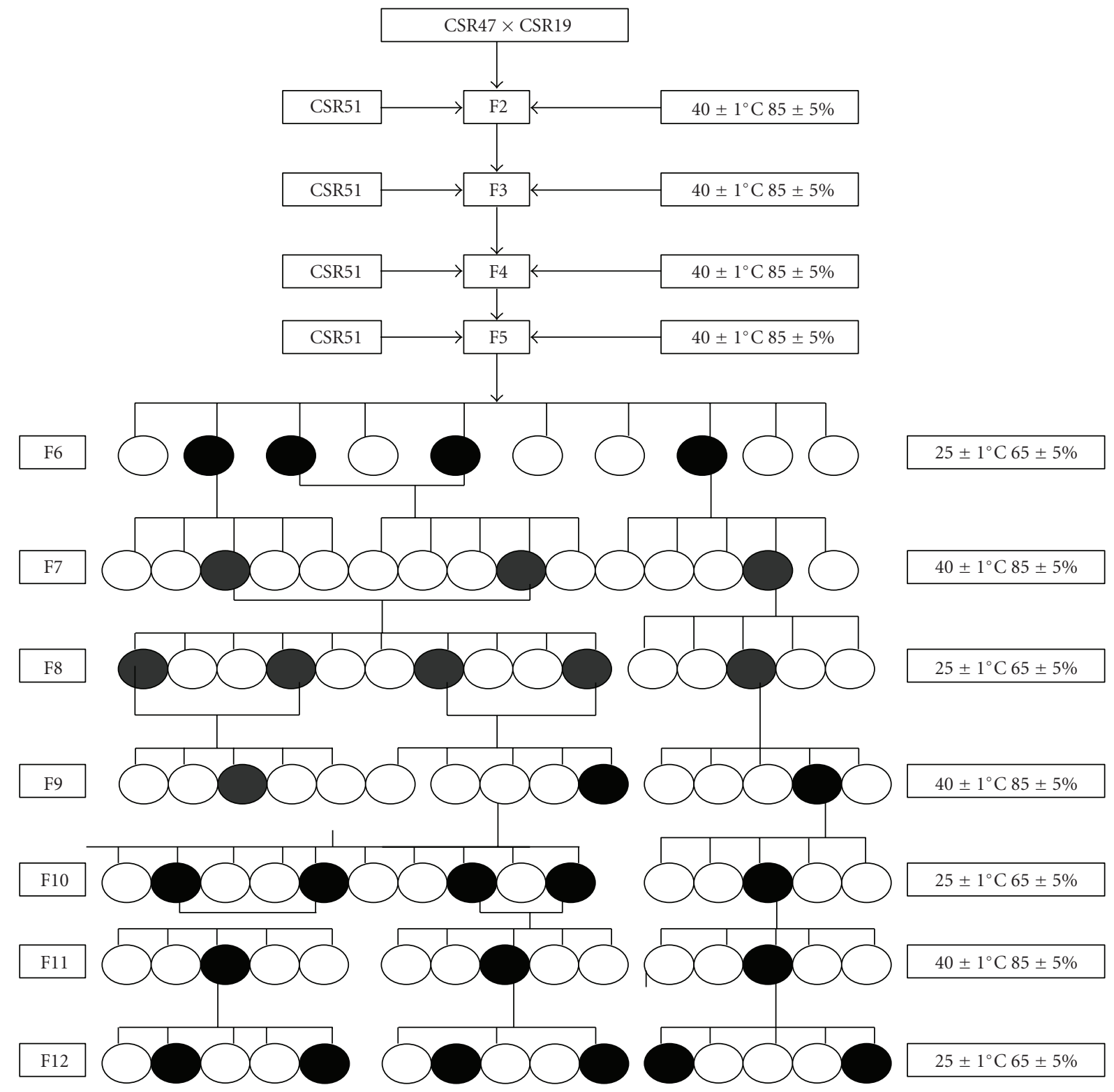

Figure 1: Breeding plan for HH8.

\subsection{Performance of HH10 at Two Temperature Conditions}

3.2.1. Rearing Performance. Generation wise mean performance for rearing of HH10 is presented in Table 4. Highest fecundity (597) at F3 and lowest (554) at F8 was recorded at $40 \pm 1{ }^{\circ} \mathrm{C}$ and $50 \pm 5 \% \mathrm{RH}$. At $40 \pm 1^{\circ} \mathrm{C}$ and $50 \pm 5 \% \mathrm{RH}$, the $V$ age larval duration ranged from 132 to 138 hours with the shortest of 132 was recorded at F4, F7, and F11. However, at $25 \pm 1^{\circ} \mathrm{C}$ and $65 \pm 5 \% \mathrm{RH}$ larval span of $138 \mathrm{hrs}$ ranged from $144 \mathrm{hrs}$ to $150 \mathrm{hrs}$ (F5). The survival percentage in respect of $\mathrm{HH} 10$ at $40 \pm 1^{\circ} \mathrm{C}$ and $85 \pm 5 \% \mathrm{RH}$ ranged from 77.7 to $87.7 \%$ with the highest of $87.7 \%$ recorded at $\mathrm{F} 4$ and the lowest of $77.7 \%$ at F7. However, at $25 \pm 1{ }^{\circ} \mathrm{C}$ and $65 \pm 5 \%$ $\mathrm{RH}$ the survival percentage ranged from 91.6 to $93.5 \%$ with the highest of $93.5 \%$ at F3 and the lowest of $91.6 \%$ recorded at F4. At $40 \pm 1{ }^{\circ} \mathrm{C}$ and $85 \pm 5 \% \mathrm{RH}$, the highest cocoon yield/10000 larvae for $\mathrm{HH} 10$ was observed in $\mathrm{F} 4(16.39 \mathrm{~kg})$ and the least $(14.74 \mathrm{~kg})$ at F2. Similarly, at $25 \pm 1^{\circ} \mathrm{C}$ and $65 \pm 5 \% \mathrm{RH}$, the highest for HH10 was observed in F5 $(19.41 \mathrm{~kg})$ and the least $(16.75 \mathrm{~kg})$ at F4. The highest cocoon weight $(1.601 \mathrm{~g})$ for $\mathrm{HH} 10$ was recorded at $40 \pm 1{ }^{\circ} \mathrm{C}$ and $85 \pm 5 \% \mathrm{RH}$ in F1 and the lowest (1.521 g) at F2. Similarly, at $25 \pm 1{ }^{\circ} \mathrm{C}$ and $65 \pm 5 \% \mathrm{RH}$, the highest (1.901 g) for HH10 was observed in F5 and the lowest $(1.650 \mathrm{~g})$ in F3. The highest cocoon shell weight at $40 \pm 1^{\circ} \mathrm{C}$ and $85 \pm 5 \% \mathrm{RH}$ for $\mathrm{HH} 10$ was observed in F9 (0.342 g) and the lowest $(0.312 \mathrm{~g})$ in F2. Similarly, at $25 \pm 1{ }^{\circ} \mathrm{C}$ and $65 \pm 5 \% \mathrm{RH}$, the highest for $\mathrm{HH} 10$ was observed in F5 (0.408 g) and the lowest $(0.364 \mathrm{~g})$ in F3. The highest cocoon shell percentage at $40 \pm 1{ }^{\circ} \mathrm{C}$ and $85 \pm 5 \%$ $\mathrm{RH}$ for HH10 was observed in F9 (21.74\%) and the lowest 


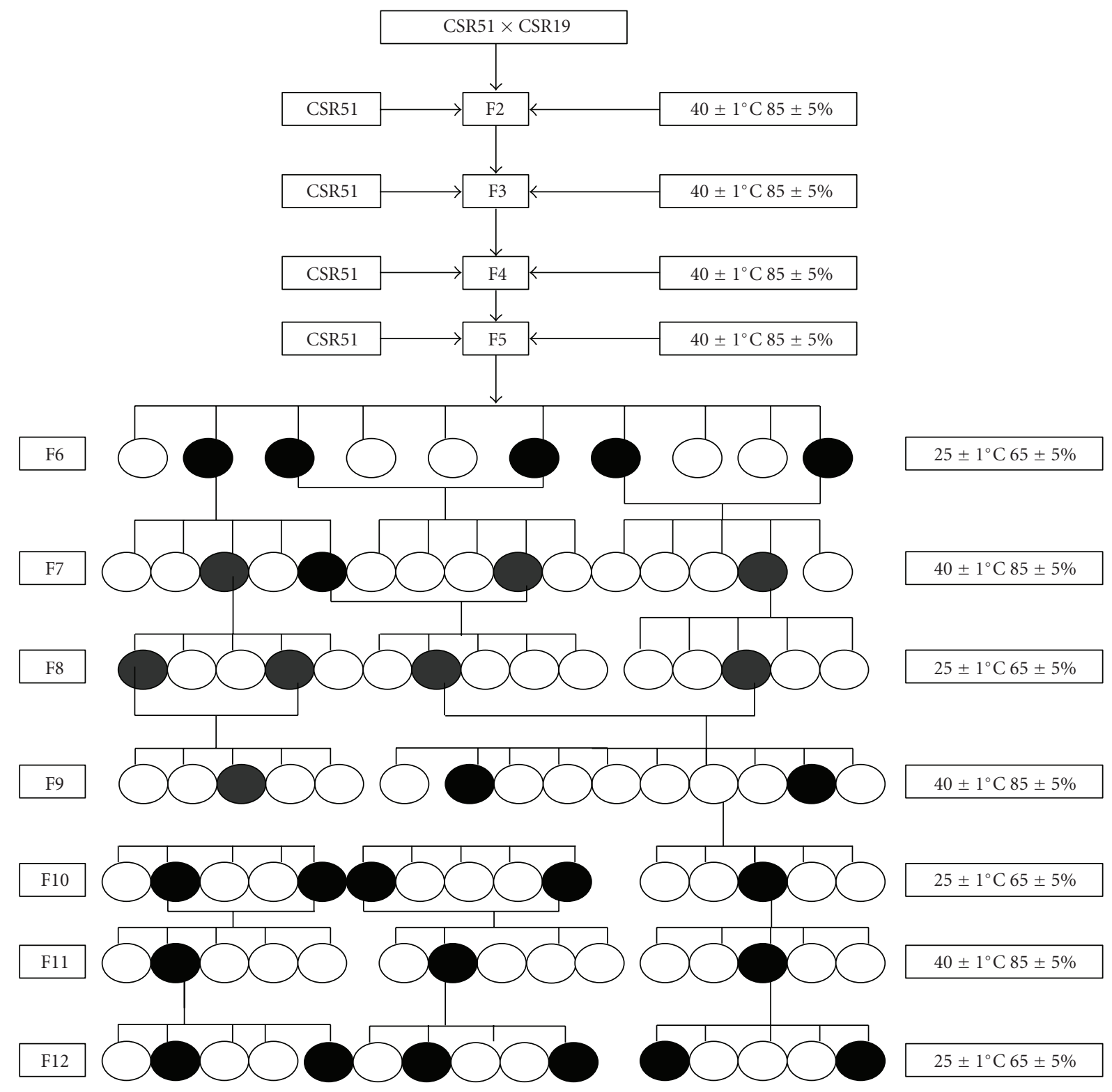

Figure 2: Breeding plan for HH10.

$(20.42 \%)$ in F1. Similarly, at $25 \pm 1{ }^{\circ} \mathrm{C}$ and $65 \pm 5 \% \mathrm{RH}$, the highest for HH10 was observed in F12 (22.29\%) and the lowest $(21.39 \%)$ in F6. Analysis of variance with regard to Yield/10000 larvae recorded highly significant difference $(P>.01)$ at $40 \pm 1^{\circ} \mathrm{C}$ and $85 \pm 5 \% \mathrm{RH}$ between generations. Similarly, at $25 \pm 1^{\circ} \mathrm{C}$ and $65 \pm 5 \% \mathrm{RH}$, Yield/10000 larvae recorded significant difference $(P>.001)$ and cocoon weight recorded significant difference $(P>.05)$ (Table 4$)$.

3.2.2. Reeling Performance. Generationwise mean performance for reeling of $\mathrm{HH} 10$ is presented in Table 5. The reelability at $40 \pm 1{ }^{\circ} \mathrm{C}$ and $85 \pm 5 \% \mathrm{RH}$ ranged from $80.33 \%$ (F11) to $82.33 \%$ (F1). Similarly, at $25 \pm 1{ }^{\circ} \mathrm{C}$ and $65 \pm 5 \%$ $\mathrm{RH}$, it ranged from $84.67 \%$ at F2 to $86.67 \%$ at F3 and F12. Longest filament length of $968 \mathrm{~m}$ was recorded at F1 and the least of $582 \mathrm{~m}$ in F3 at $40 \pm 1{ }^{\circ} \mathrm{C}$ and $50 \pm 5 \%$ RH. However, at $25 \pm 1{ }^{\circ} \mathrm{C}$ and $65 \pm 5 \% \mathrm{RH}$, the longest of $1106 \mathrm{~m}$ was recorded in F10 and least of $967 \mathrm{~m}$ in (F2). Lowest renditta of 6.30 was observed at $\mathrm{F} 9$ and it ranged from 6.30 to 6.73 (F7) at $40 \pm 1{ }^{\circ} \mathrm{C}$ and $85 \pm 5 \% \mathrm{RH}$. However, at $25 \pm 1^{\circ} \mathrm{C}$ and $65 \pm 5 \% \mathrm{RH}$, it ranged from 5.65 (F10) to 5.86 (F6). The highest raw silk percentage at $40 \pm 1{ }^{\circ} \mathrm{C}$ and $85 \pm 5 \%$ $\mathrm{RH}$ was recorded in F9 (15.87\%) and the lowest (14.86\%) in F7. Similarly, at $25 \pm 1{ }^{\circ} \mathrm{C}$ and $65 \pm 5 \% \mathrm{RH}$, the highest was observed in F10 (17.70\%) and the lowest (17.08\%) in F6. Thinner filament size of 2.36 was observed at $\mathrm{F} 9$ and it ranged from 2.36 to $2.54 \mathrm{~d}(\mathrm{~F} 4)$ at $40 \pm 1{ }^{\circ} \mathrm{C}$ and $85 \pm 5 \%$ RH. Similarly, at $25 \pm 1{ }^{\circ} \mathrm{C}$ and $65 \pm 5 \% \mathrm{RH}$, it ranged from $2.54 \mathrm{~d}$ (F2) to $3 \mathrm{~d}$ (F5). Highest neatness at $40 \pm 1{ }^{\circ} \mathrm{C}$ and $85 \pm 5 \%$ RH was observed in F7 and F11 (90.67 p) and the 


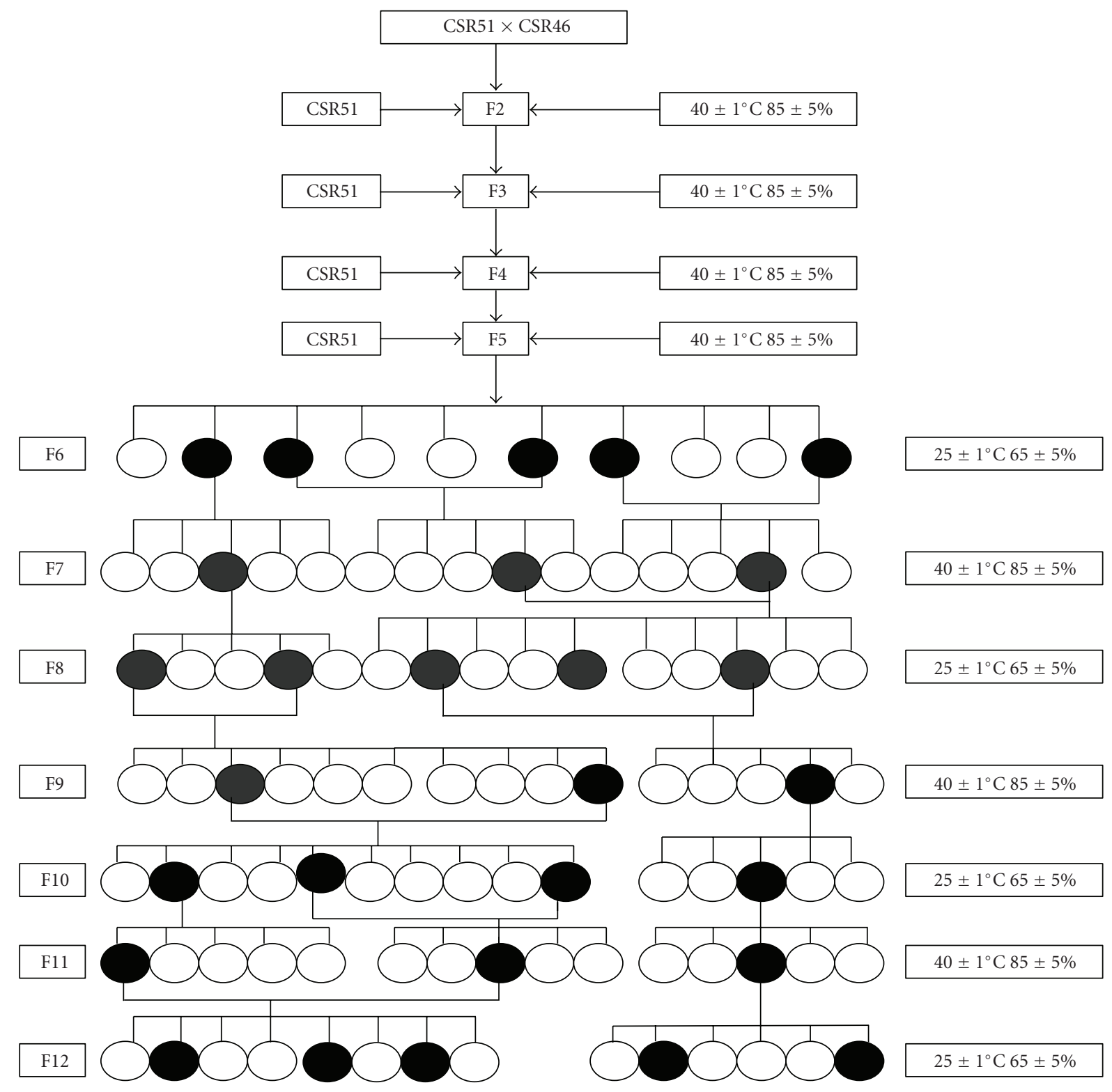

FIgURE 3: Breeding plan for HH12.

lowest (89.33 p) in (F5). Similarly, at $25 \pm 1^{\circ} \mathrm{C}$ and $65 \pm 5 \%$ $\mathrm{RH}$, the highest was observed in F4 and F6 (92.67 p) and the lowest (90.67 p) in F7 and F11. Analysis of variance for reeling of $\mathrm{HH} 10$ showed nonsignificant differences for all the traits at $40 \pm 1{ }^{\circ} \mathrm{C}$ and $85 \pm 5 \% \mathrm{RH}$. However at $25 \pm 1{ }^{\circ} \mathrm{C}$ and $65 \pm 5 \% \mathrm{RH}$, with regard to filament length $(\mathrm{m})$, filament size $(\mathrm{d})$ recorded highly significant difference $(P>.001)$, and reelability recorded significant difference $(P>.01)$ (Table 5).

\subsection{Performance of HH12 at Two Temperature Conditions}

3.3.1. Rearing Performance. Generation wise mean performance for rearing of $\mathrm{HH} 12$ is presented in Table 6. Highest fecundity (591) of $\mathrm{HH} 1$ was recorded at F8 and lowest (560) was recorded at $\mathrm{F} 5$ at $40 \pm 1^{\circ} \mathrm{C}$ and $50 \pm 5 \% \mathrm{RH}$. At $40 \pm 1^{\circ} \mathrm{C}$ and $50 \pm 5 \% \mathrm{RH}$, the $V$ age larval duration ranged from 132 to 138 hours with the shortest of 132 was recorded at F4, F7, and F11. However, at $25 \pm 1^{\circ} \mathrm{C}$ and $65 \pm 5 \% \mathrm{RH} V$ age larval span ranged from $144 \mathrm{hrs}$ to $150 \mathrm{hrs}$ (F5). The survival percentage in respect of $\mathrm{HH} 12$ at $40 \pm 1^{\circ} \mathrm{C}$ and $85 \pm 5 \%$ $\mathrm{RH}$ ranged from 77.3 to $85.0 \%$ with the highest of $85.0 \%$ recorded at $\mathrm{F} 7$ and the lowest of $77.3 \%$ at F1. However, at $25 \pm 1^{\circ} \mathrm{C}$ and $65 \pm 5 \% \mathrm{RH}$ the survival percentage ranged from 91.1 to $94.4 \%$ with the highest of $94.4 \%$ at F3 and the lowest of $91.1 \%$ recorded at $\mathrm{F} 7$. At $40 \pm 1^{\circ} \mathrm{C}$ and $85 \pm 5 \% \mathrm{RH}$, the highest cocoon Yield/10000 larvae for HH12 was observed in F9 $(16.42 \mathrm{~kg})$ and the least $(13.74 \mathrm{~kg})$ at F7. Similarly, at $25 \pm 1^{\circ} \mathrm{C}$ and $65 \pm 5 \% \mathrm{RH}$, the highest for $\mathrm{HH} 12$ was observed in F5 $(19.81 \mathrm{~kg})$ and the least $(18.47 \mathrm{~kg})$ at F8. The highest cocoon weight $(1.600 \mathrm{~g})$ for $\mathrm{HH} 12$ was recorded at $40 \pm 1^{\circ} \mathrm{C}$ 


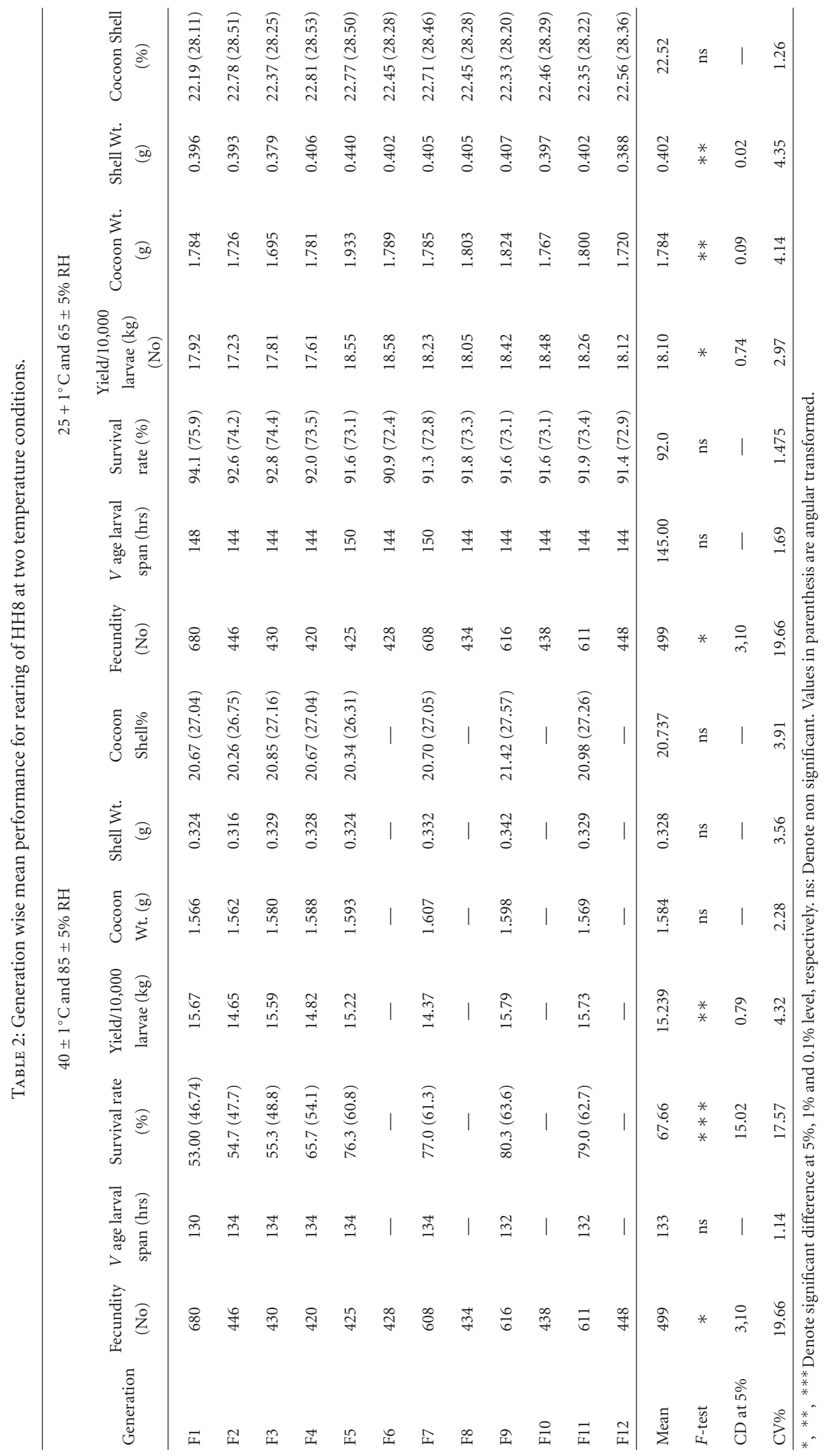




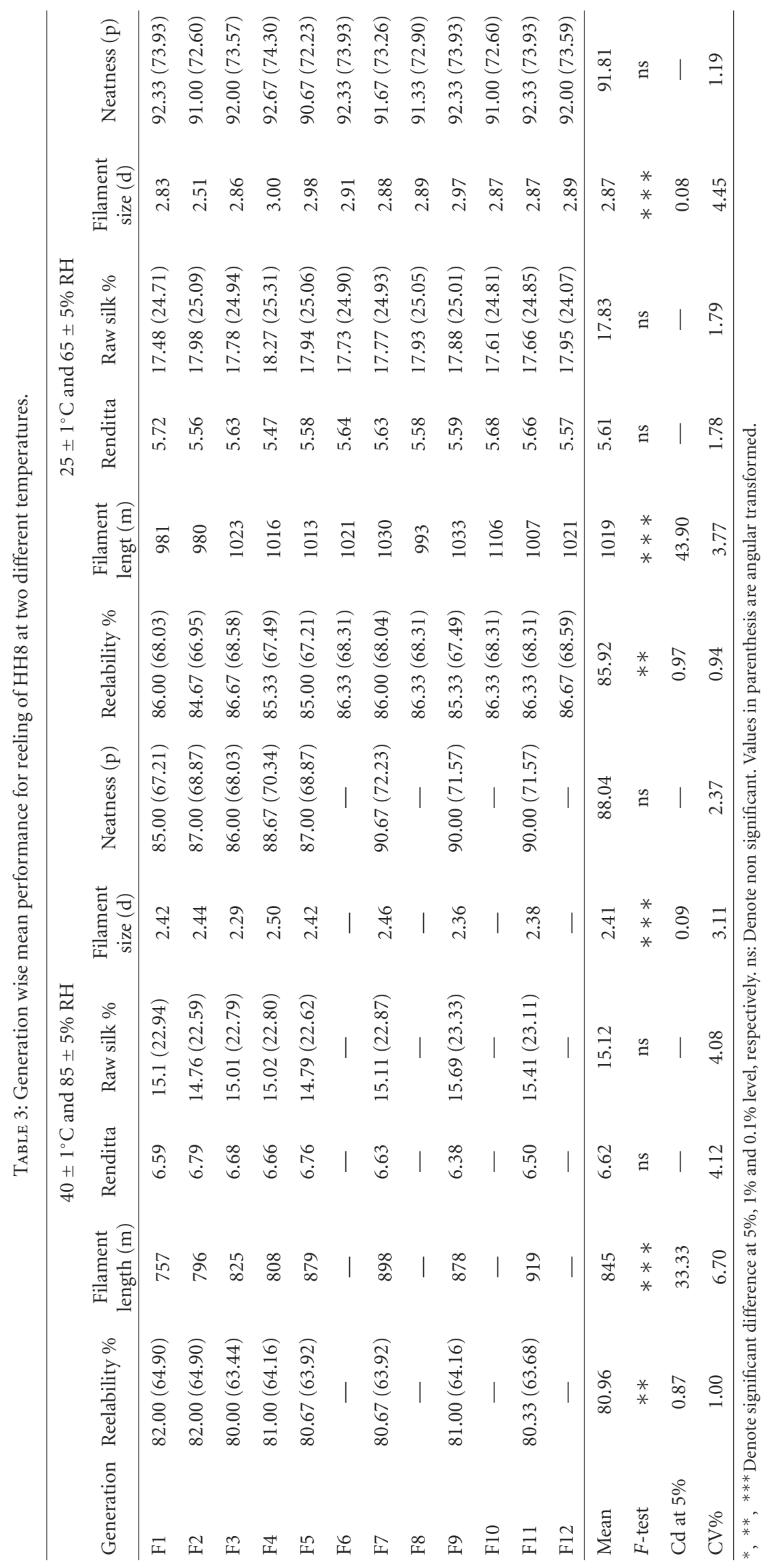




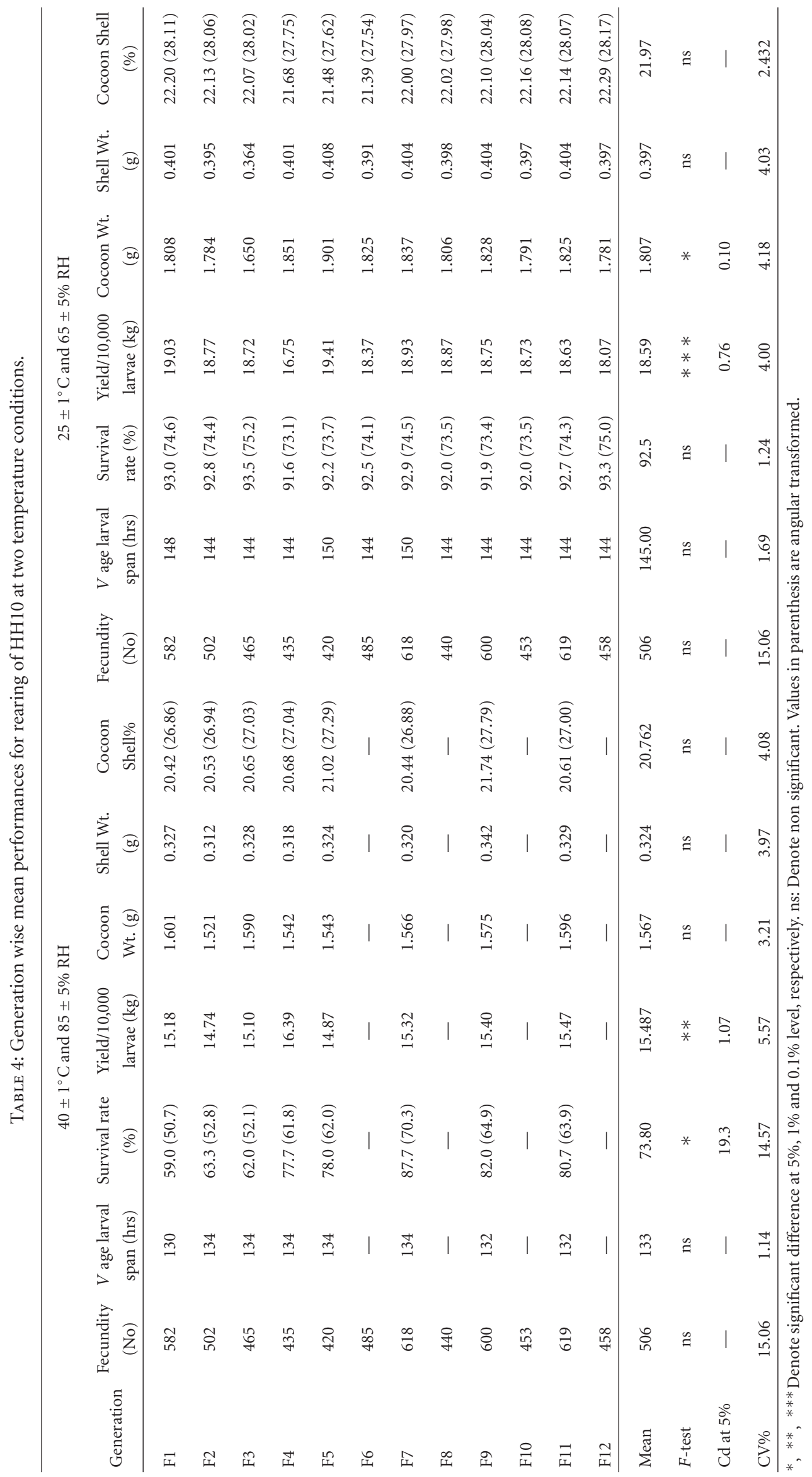




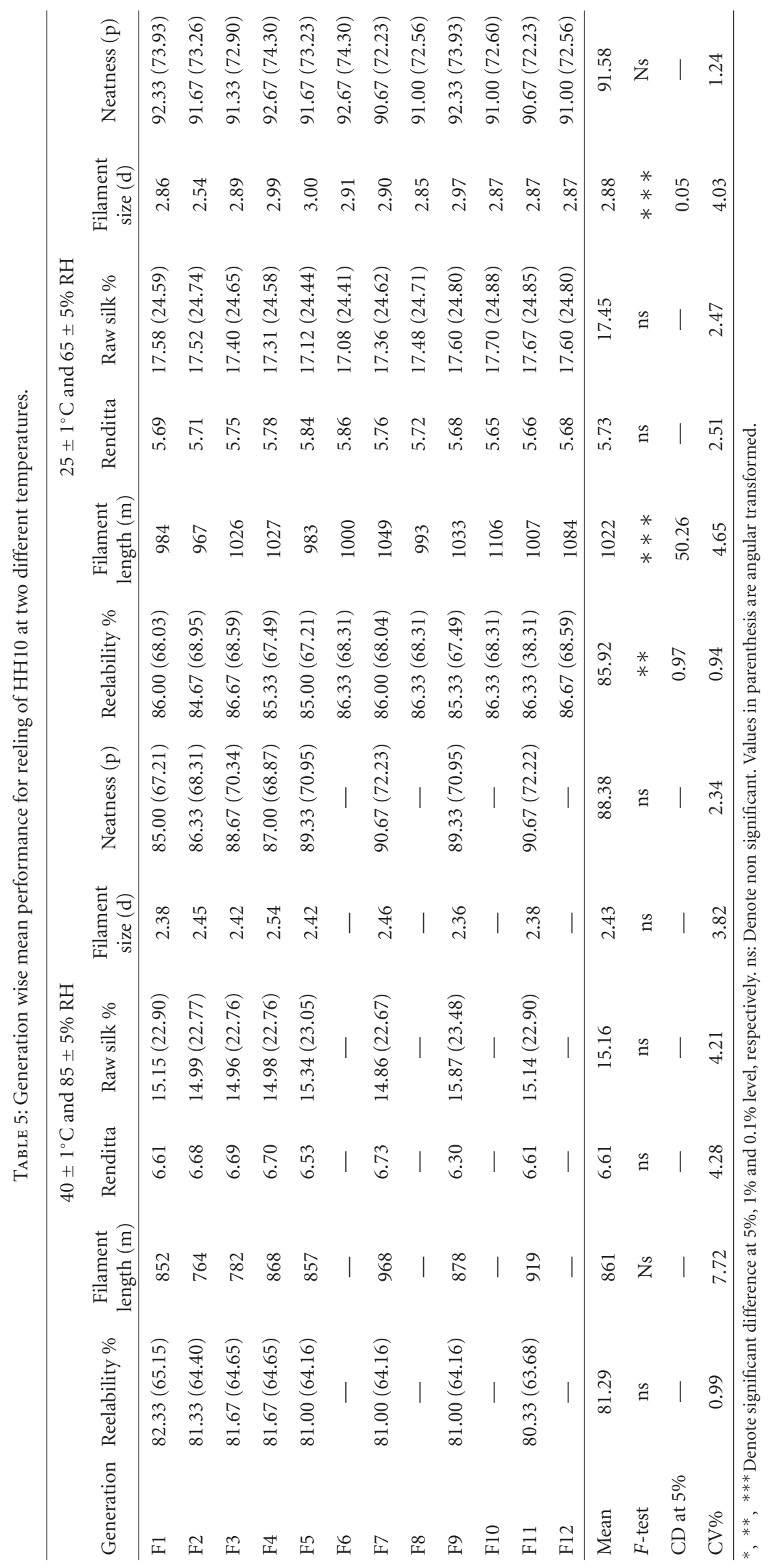




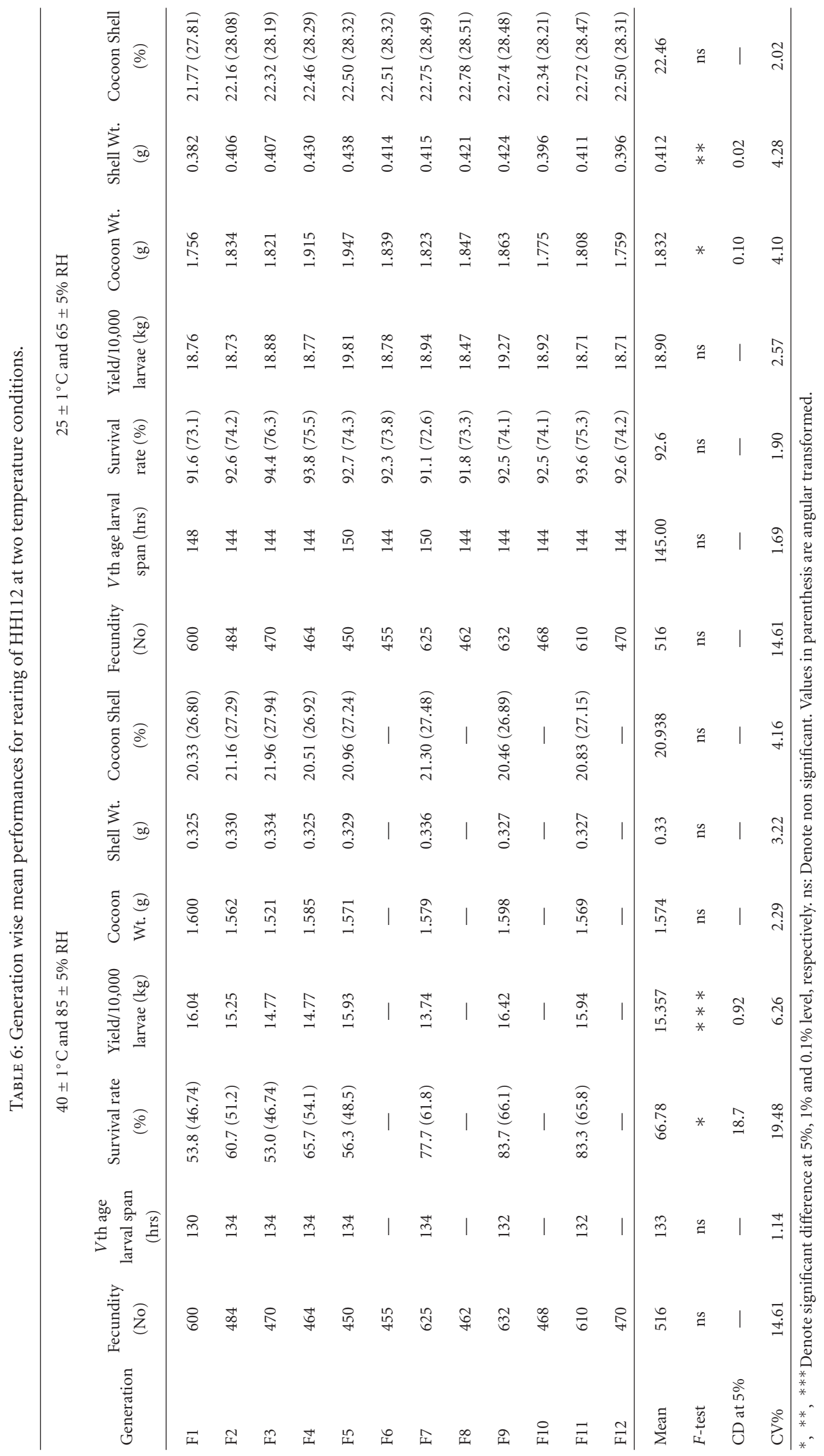


and $85 \pm 5 \% \mathrm{RH}$ in F1 and the lowest $(1.521 \mathrm{~g})$ at F3. Similarly, at $25 \pm 1{ }^{\circ} \mathrm{C}$ and $65 \pm 5 \% \mathrm{RH}$, the highest for HH12 was observed in F5 (1.947 g) and the lowest (1.756 g) in F1. The highest cocoon shell weight at $40 \pm 1^{\circ} \mathrm{C}$ and $85 \pm 5 \% \mathrm{RH}$ for $\mathrm{HH} 12$ was observed in F7 (0.336 g) and the lowest $(0.325 \mathrm{~g})$ in F1 and F4. Similarly, at $25 \pm 1^{\circ} \mathrm{C}$ and $65 \pm 5 \% \mathrm{RH}$, the highest for $\mathrm{HH} 12$ was observed in F5 (0.438 g) and the lowest $(0.382 \mathrm{~g})$ in $\mathrm{F} 1$. The highest cocoon shell percentage at $40 \pm$ $1{ }^{\circ} \mathrm{C}$ and $85 \pm 5 \% \mathrm{RH}$ for $\mathrm{HH} 12$ was observed in $\mathrm{F} 3(21.96 \%)$ and the lowest $(20.33 \%)$ in F1. Similarly, at $25 \pm 1{ }^{\circ} \mathrm{C}$ and $65 \pm 5 \% \mathrm{RH}$, the highest for $\mathrm{HH} 12$ was observed in F8 $(22.78 \%)$ and the lowest $(21.77 \%)$ in F1. Analysis of variance with regard to Yield/10000 larvae recorded highly significant difference $(P>.001)$ at $40 \pm 1^{\circ} \mathrm{C}$ and $85 \pm 5 \%$ RH between generations. Similarly, at $25 \pm 1{ }^{\circ} \mathrm{C}$ and $65 \pm 5 \% \mathrm{RH}$, shell weight recorded significant difference $(P>.01)$ and cocoon weight recorded significant difference $(P>.05)$ (Table 6).

3.3.2. Reeling Performance. Generation wise mean performance for reeling of $\mathrm{HH} 12$ is presented in Table 7.The reelability at $40 \pm 1^{\circ} \mathrm{C}$ and $85 \pm 5 \% \mathrm{RH}$ ranged from $80.67 \%$ (F2), (F5), (F7) and (F11) to 82\% (F3) and (F9). Similarly, at $25 \pm 1^{\circ} \mathrm{C}$ and $65 \pm 5 \% \mathrm{RH}$, it ranged from $83.33 \%$ at $\mathrm{F} 4$ to $86.67 \%$ at F12. Longest filament length of $976 \mathrm{~m}$ was recorded at $\mathrm{F} 1$ and the least of $887 \mathrm{~m}$ in $\mathrm{F} 5$ at $40 \pm 1{ }^{\circ} \mathrm{C}$ and $50 \pm 5 \% \mathrm{RH}$. However, at $25 \pm 1^{\circ} \mathrm{C}$ and $65 \pm 5 \% \mathrm{RH}$, the longest $1077 \mathrm{~m}$ was recorded in F3 and least $963 \mathrm{~m}$ in (F5). Lowest renditta of 6.28 was observed at $\mathrm{F} 3$ and it ranged from 6.28 to $6.82(\mathrm{~F} 4)$ at $40 \pm 1^{\circ} \mathrm{C}$ and $85 \pm 5 \% \mathrm{RH}$. However, at $25 \pm 1{ }^{\circ} \mathrm{C}$ and $65 \pm 5 \% \mathrm{RH}$, it ranged from $5.53(\mathrm{~F} 8)$ to 5.83 (F3). The highest raw silk percentage at $40 \pm 1^{\circ} \mathrm{C}$ and $85 \pm 5 \% \mathrm{RH}$ was recorded in F3 (15.94\%) and the lowest $(14.68 \%)$ in F4. Similarly, at $25 \pm 1^{\circ} \mathrm{C}$ and $65 \pm 5 \% \mathrm{RH}$, the highest was observed in F8 (18.08\%) and the lowest (17.16\%) in F1. Thinner filament size of 2.37 was observed at F9 and it ranged from 2.37 to $2.69 \mathrm{~d}(\mathrm{~F} 7)$ at $40 \pm 1^{\circ} \mathrm{C}$ and $85 \pm 5 \%$ $\mathrm{RH}$. Similarly, at $25 \pm 1^{\circ} \mathrm{C}$ and $65 \pm 5 \% \mathrm{RH}$, it ranged from $2.63 \mathrm{~d}(\mathrm{~F} 2)$ to $3.01 \mathrm{~d}(\mathrm{~F} 4)$. Highest neatness at $40 \pm 1^{\circ} \mathrm{C}$ and $85 \pm 5 \% \mathrm{RH}$ was observed in F7 and F11 (90.33 p) and the lowest (85.33 p) in (F1). Similarly, at $25 \pm 1^{\circ} \mathrm{C}$ and $65 \pm 5 \%$ $\mathrm{RH}$, the highest was observed in F1, F3, F9 and F11 (92.33 p) and the lowest (90.67 p) in F5 and F7. Analysis of variance with regard to filament length $(\mathrm{m})$, filament size $(\mathrm{d})$ recorded highly significant difference $(P>.001)$ at $40 \pm 1^{\circ} \mathrm{C}$ and $85 \pm 5 \% \mathrm{RH}$ between generations. Similarly, at $25 \pm 1{ }^{\circ} \mathrm{C}$ and $65 \pm 5 \% \mathrm{RH}$, reelability, filament size (d) recorded highly significant difference $(P>.001)$ and filament length $(\mathrm{m})$ recorded significant difference $(P>.05)$ (Table 7$)$.

\section{Discussion}

The breeding of silkworm since long has been aimed towards evolving of superior and hardy breeds either by means of selection alone or by combining outcrossing or backcrossing with selection in the subsequent generations. The final aim of the breeder is primarily to evolve a breed which can give rise to stabilized crops and secondly to improve both quantity and quality of silk [11]. The breeding of silkworm races probably dates back to the beginning of the history of silkworm rearing, but it has made great progress rather recently [12]. Sericulturally advanced countries like Japan has achieved remarkable progress by executing systematic breeding plans for the development of productive races. In silkworms, studies carried out for various characters have shown that the characters could be changed to suit the breeders choice, since selection for one trait has correlation with genetic change of other characters. The correlation for few traits is negative and for some it is positive [13-16]. Therefore, during the course of breeding of new breeds, the breeder has to be aware of the response of certain characters in selection and its correlated changes with other economic traits. Inbreeding of hybrids to stabilize silkworm breeds which bred true is well documented [12, 16-26]. Similarly, Kovolov [27] is of the opinion that improvement of silkworm races is possible by outbreeding with exotic races and improvement of cocoon quality by repeated backcrossing [28].

According to Allard and Bradshaw [29], performance of the strain itself in a given environment indicates its superiority. During evaluation, emphasis was given on the phenotypic expression of traits of economic importance under different temperature conditions. However, as the objective of the study was for greater viability and high productivity merits, equal importance was given on these two traits during selection of parents. The significant variations observed in the phenotypic manifestation for the traits analyzed can be attributed to the genetic constitution of the breeds and their degree of expression to which they are exposed during their rearing. Such variations in the manifestation of phenotypic traits of the breeds studied can be ascribed to the influence of environmental conditions. Variable gene frequencies at different loci make them to respond differently. The results are in line with the findings of [29-39].

In the present breeding programme, which envisages evolution of new hardy bivoltines, the aim was to develop more resistant bivoltines that can give rise to stable cocoon crops with better viability, even though productivity is low compared to the existing productive bivoltine breeds that are currently used in the field. In silkworms, the correlation for some characters is positive and for some is negative $[15,16]$. Such a negative correlation is observed for the traits productivity and viability and hence the attempt made was to increase the viability of the developed breeds. Moreover as suggested by $[40,41]$, the selection parameters were primarily aimed at improving the viability character such as yielded by number without sacrificing much of the productivity traits like cocoon weight, cocoon shell weight, and yield by weight. In addition, during later generations of inbreeding, selection was applied to select desired genotypes to improve the traits of commercial importance like viability and productivity as suggested by $[42,43]$ to improve the yield of bivoltines.

The imposition of exposure to high temperature levels in 5th instar and the resultant low pupation rate could be attributed to the low feeding activity of the silkworm resulting in the physiological imbalance and poor health of the larvae and an increased number of nonspinning worms in the mountages. The work in [44] demonstrated that silkworms are more sensitive to high temperature during 


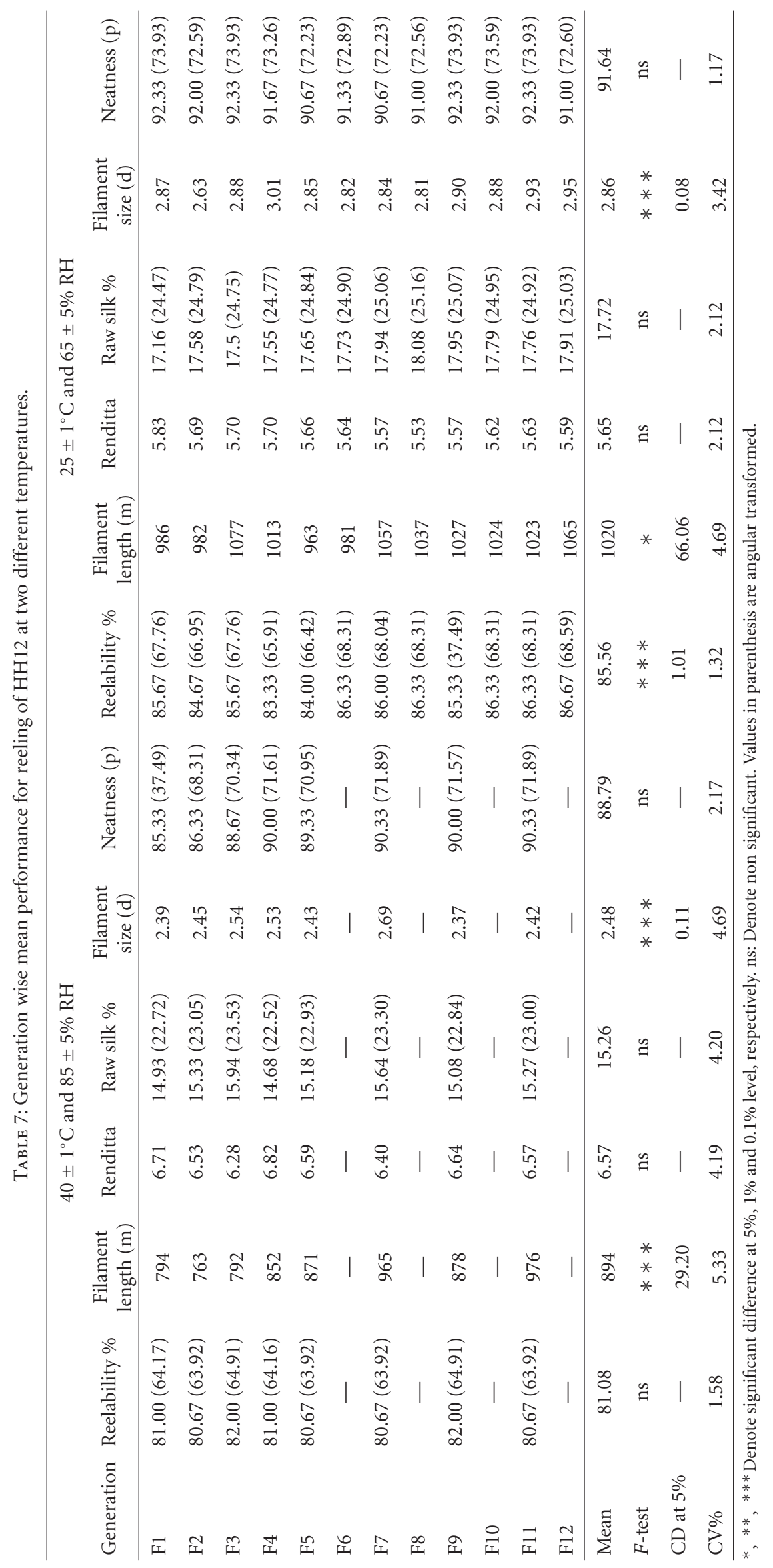


4th and 5th instars. The productive bivoltine breeds are reported to be susceptible to high temperature; the authors of $[8,45]$ noticed higher survival in the hybrids than the pure races under high temperature conditions. In the present investigation, when lines are exposed to high temperature continuously there is a drastic reduction in the pupation rate and cocoon traits. The work in [46] observed that at high temperature $\left(35^{\circ} \mathrm{C}\right)$ and low humidity $(50 \pm 5 \%)$ and high humidity $(85 \pm 5 \%)$ conditions, pupation rate was drastically reduced in productive hybrid, CSR2 $\times$ CSR5. Such drastic change is usually obtained as it is low heritable trait in the silkworm and is prone to large variations in environment and management [47]. The work in [48] observed that the pupation rate in Indian popular bivoltine breed, NB4D2, is significantly influenced by both low and high humidity.

Silkworm breed which are reared over a series of environments exhibiting less variation are considered stable. One of the objectives of the breeder is to recommend stable breeds to the farmers for rearing under different environmental conditions. Effect of high temperature and low humidity in terms of cocoon crop depends on several factors that operate within and outside the body of the silkworm. In the present study, it was observed that apart from the temperature, humidity also influences the productivity pattern in the silkworm and is in agreement with $[49,50]$. It was also observed that the cocoon Yield/10000 larvae, cocoon weight, cocoon shell weight, and cocoon shell percentage were also low in the high temperature treated batches when compared to the batches reared under optimum rearing conditions. The work in [51] reported the deleterious effect of high temperature and high humidity on quantitative traits of parents, foundation crosses, and single and double hybrids of bivoltine silkworm breeds of Bombyx mori L.

\section{References}

[1] N. Suresh Kumar, "Breeding techniques," in A Text Book on Silkworm Breeding and Genetics, pp. 39-42, Central Silk Board, Bangalore, India, 2005.

[2] H. K. Basavaraja, "New productive bivoltine hybrids," Indian Silk, vol. 34, no. 2, pp. 5-9, 1995.

[3] K. V. Benchamin and M. S. Jolly, "Principles of silkworm rearing," in Proceedings of Seminar on Problems and Prospects of Sericulture, S. Mahalingam, Ed., pp. 63-106, Vellore, India, 1986.

[4] S. Krishanaswami, M. N. Narasimhanna, S. K. Surayanarayana, and S. Kumararaj, "Manual on sericulture," Vol 2., Silkworm rearing UN Food and Agriculture Organisation, Rome, Italy, pp. 54-88, 1973.

[5] F. K. Hsieh, S. Yu, S. Y. Su, and S. J. Peng, tudies on the thermotolerance of the silkworm, Bombyx mori L. Zsongriva, 1995.

[6] R. K. Datta, H. K. Basavaraja, N. Suresh Kumar, C. M. Kishor Kumar, and S. Nirmal Kumar, "Evolution of robust hybrids of bivoltine silkworm, Bombyx mori L. for tropics," in Proceedings of the 17th Congress of the International Sericulture Commission, Brazil, April 1997.

[7] N. Suresh Kumar, H. K. Basavaraja, C. M. Kishor Kumar, N. Mal Reddy, and R. K. Datta, "On the breeding of "CSR18 x CSR19"- A robust bivoltine hybrid of silkworm, Bombyx mori L. for the tropics," International Journal of Industrial Entomology, vol. 5, no. 2, pp. 155-162, 2002.
[8] M. Kato, K. Nagayasu, O. Ninagi, W. Hara, and A. Watanabe, "Studies on resistance of the silkworm, Bombyx mori L. for high temperature," in Proceedings of the 6th International Congress of SABRAO (II), pp. 953-956, 1989.

[9] T. Shirota, "Selection of healthy silkworm strain through high temperature rearing of fifth instar larvae," Reports of the Silk Science Research Institute, vol. 40, pp. 33-40, 1992.

[10] Y. Tazima and A. Ohnuma, "Preliminary experiments on the breeding procedure for synthesizing a high temperature resistant commercial strain of the silkworm, Bombyx mori L.," Silk. Sci. Res. Inst. Japan, vol. 43, pp. 1-16, 1995.

[11] Y. Tazima, Silkworm Moth, Evolution of Domesticated Animals, Longman, New York, NY, USA, 1984.

[12] T. Hirobe, "Evolution, differentiation and breeding of the silkworm-the silk road-past and present," in Proceedings of the 12th International Congress of Human Genetics (ICHG '68), pp. 25-26, Tokyo, Japan, 1968.

[13] S. Tsuchiya and H. Kurashima, "Studies on the heritability of measurable characters in Bombyx mori (III) Heritability in the hybrids of two different strains," J. Seric. Sci. Japan, vol. 27, no. 4, pp. 253-256, 1959.

[14] H. Ohi, T. Miyahara, and A. Yamashita, "Analysis of various practically important characteristics in the silkworm in early breeding generation of hybrids, variation among strains, correlation between parents and offspring as well as relationship between each character," Technical Bulletin Services Experiment Station, MAFF, vol. 93, pp. 39-49, 1970.

[15] T. Gamo and S. Ichiba, "Selection experiments on the fibroin hydrolyzing ratio in silkworm cocoons and its effects upon the economical characters," Japanese Journal of Breeding, vol. 21, no. 2, pp. 87-92, 1971.

[16] T. Gamo, "Recent concepts and trends in silkworm breeding," Farming Japan, vol. 10, no. 6, pp. 11-22, 1976.

[17] K. Osawa and C. Harada, "Studies on the F1 hybrids of the silkworm III On the effect of heterosis," Bull. Seric. Expt. Stn.Japan., vol. 12, pp. 183-211, 1944.

[18] C. Harada, "On the double cross of the silkworm," Japanese Journal of Breeding, vol. 2, no. 2, p. 3, 1952.

[19] C. Harada, "On the three way cross of the silkworm," Japanese Journal of Breeding, vol. 3, no. 3\&4, p. 99, 1953.

[20] C. Harada, "On the relation between commercial characters and their hybrids in Bombyx mori L.", in Proceedings of the International Wheat Genet Symposium, pp. 252-356, 1956.

[21] T. Hirobe, "An analysis of heterosis made with the silkworms," in Proceedings of the International Genetics Symposium, pp. 357-361, The Science Council of Japan, Tokyo, Japan, 1956.

[22] T. Hirobe, "Advancement in the improvement of silkworm varieties," Heredity, vol. 21, pp. 18-24, 1967.

[23] T. Yokoyama, "On the application of heterosis in Japanese sericulture," in Proceedings of the International Genet Symposium, pp. 527-531, 1956.

[24] T. Yokoyama, Silkworm Genetics Illustrated, Japan Society for the Promotion of Sciences, Tokyo, India, 1959.

[25] T. Yokoyama, "Breeding silkworm," Sci. \& Tech.In Seric., vol. 15, no. 4, pp. 58-61, 1976.

[26] T. Yokoyama, "Silkworm selection and hybridization," in Genetics in relation to insect management. Working papers. The rockfeller Foundation Management, pp. 71-83, 1979.

[27] P. A. Kovolov, Silkworm Breeding Techniques, Central Silk Board, Bombay, India, 1970.

[28] Y. Tazima, The Genetics of the Silkworm, Logos Press, London, UK, 1964. 
[29] R. B. Allard and A. O. Bradshaw, "Implications of genotype environment interaction in applied plant breeding," Crop Science, vol. 4, pp. 503-506, 1964.

[30] K. Watanabe, "Further studies on the voltinism in the silkworm, Bombyx mori L.," Bull. Seric. Exp. Stn. Jpn., vol. 7, pp. 285-303, 1928.

[31] S. Krishnaswami and M. N. Narasimhanna, "Large scale trials of bivoltine hybrids in Mysore state," Indian Journal of Genetics and Plant Breeding, vol. 34, pp. 229-236, 1974.

[32] S. Ueda, R. Kimura, and K. Suzuki, "Studies on the growth of the silkworm, Bombyx mori L. IV Mutual relationship between the growth in the fifth instar larvae productivity of silk substance and eggs," Bull. seric. Expt. Stn. Japan., vol. 26, no. 3, pp. 233-247, 1975.

[33] G. S. Rajanna, Evolution of suitable bivoltine races of silkworm, Bombyx mori L. for tropics, Ph.D. thesis, University of Mysore, Mysore, India, 1989.

[34] P. J. Raju, Studies on the hybridization and synthesis of new breeds of silkworm, Bombyx mori L., Ph.D. thesis, University of Mysore, Mysore, India, 1990.

[35] V. G. Maribashetty, Evolution of superior bivoltine races of silkworm Bombyx mori l for tropics, Ph.D. thesis, University of Mysore, Mysore, India, 1991.

[36] G. V. Kalpana, Breeding of superior races of silkworm, Bombyx mori L. for tropical climates, Ph.D. thesis, University of Mysore, Mysore, India, 1992.

[37] S. Nirmal Kumar, Studies on the synthesis of appropriate silkworm breed (Bombyx mori L) for tropics, Ph.D. thesis, University of Mysore, Mysore, India, 1995.

[38] H. K. Basavaraja, Studies on the synthesis of productive bivoltine strains of Bombyx mori L. through hybridization, selection and genetic evaluation, Ph.D. thesis, University of Mysore, Mysore, India, 1996.

[39] P. Sudhakar Rao, R. Singh, G. V. Kalpana, V. Nishitha Naik, H. K. Basavaraja, and G. N. Ramaswamy, "Evaluation and identification of promising bivoltine hybrids of silkworm, Bombyx mori L. for tropics," International Journal of Industrial Entomology, vol. 3, no. 1, pp. 31-35, 2001.

[40] P. Lekuthai and S. Butrachand, "Improvement of bivoltine silkworm races," Bull. Thai. Seric. Res. Trai. Cent., vol. 2, pp. 48-54, 1974.

[41] V. A. Strunnikov and L. V. Strunnikov, "The nature of genes controlling the silk productivity of silkworm cocoons," Doklady Akademii Nauk SSSR, vol. 290, no. 1, pp. 234-237, 1986.

[42] Mano Y., Observations on silkworm breeding in India, A report- Submitted to CSB, Bangalore 1-2,1993.

[43] Mano Y., A comprehensive report on silkworm breeding Submitted to CSB, Bangalore 1-180, 1994.

[44] S. Ueda and H. Lizuka, "Studies on the effects of rearing temperature affecting the health of silkworm larvae and upon the quality of cocoons-1 Effect of temperature in each instar," Acta Sericologia in Japanese, vol. 41, pp. 6-21, 1962.

[45] N. Suresh Kumar, T. Yamamoto, H. K. Basavaraja, and R. K. Datta, "Studies on the effect of high temperature on F1 hybrids between polyvoltines and bivoltine silkworm races of Bombyx mori L.," International Journal of Industrial Entomology, vol. 2, no. 2, pp. 123-127, 2001.

[46] K. M. Vijaya Kumari, M. Balavenkatasubbiah, R. K. Rajan, H. T. Himantharaj, B. Nataraj, and M. Rekha, "Influence of temperature and relative humidity on the rearing performance and disease incidence in CSR hybrid silkworms, Bombyx mori
L." International Journal of Industrial Entomology, vol. 3, no. 2, pp. 113-116, 2001.

[47] T. Gamo and T. Hirabayashi, "Genetic analysis of growth rate, pupation rate and some quantitative characters by diallel crosses in silkworm, Bombyx mori L.", Japanese Journal of Breeding, vol. 33, no. 2, pp. 178-190, 1983.

[48] P. L. Reddy, S. Sankar Naik, and N. Sivarami Reddy, "Implications of temperature and humidity on pupation patterns in the silkworm, Bombyx mori L.", International Journal of Industrial Entomology, vol. 5, no. 1, pp. 67-71, 2002.

[49] S. Krishnaswami, Improved Methods of Rearing Young Age ( chawki) Silkworms, CSRTI, Bombay, India, 1986.

[50] P. Sudhakar Rao, Studies on the evolution of adaptive bivoltine breeds of silkworm, Bombyx mori $L$ for tropical climates, Ph.D. thesis, University of Mysore, Mysore, India, 2003.

[51] N. Suresh Kumar, H. K. Basavaraja, N. Mal Reddy, and S. B. Dandin, "Effect of high temperature and high humidity on the quantitative traits of parents, foundation crosses, single and double hybrids of bivoltine silkworm, Bombyx mori L.," International Journal of Industrial Entomology, vol. 6, no. 2, pp. 197-202, 2003. 

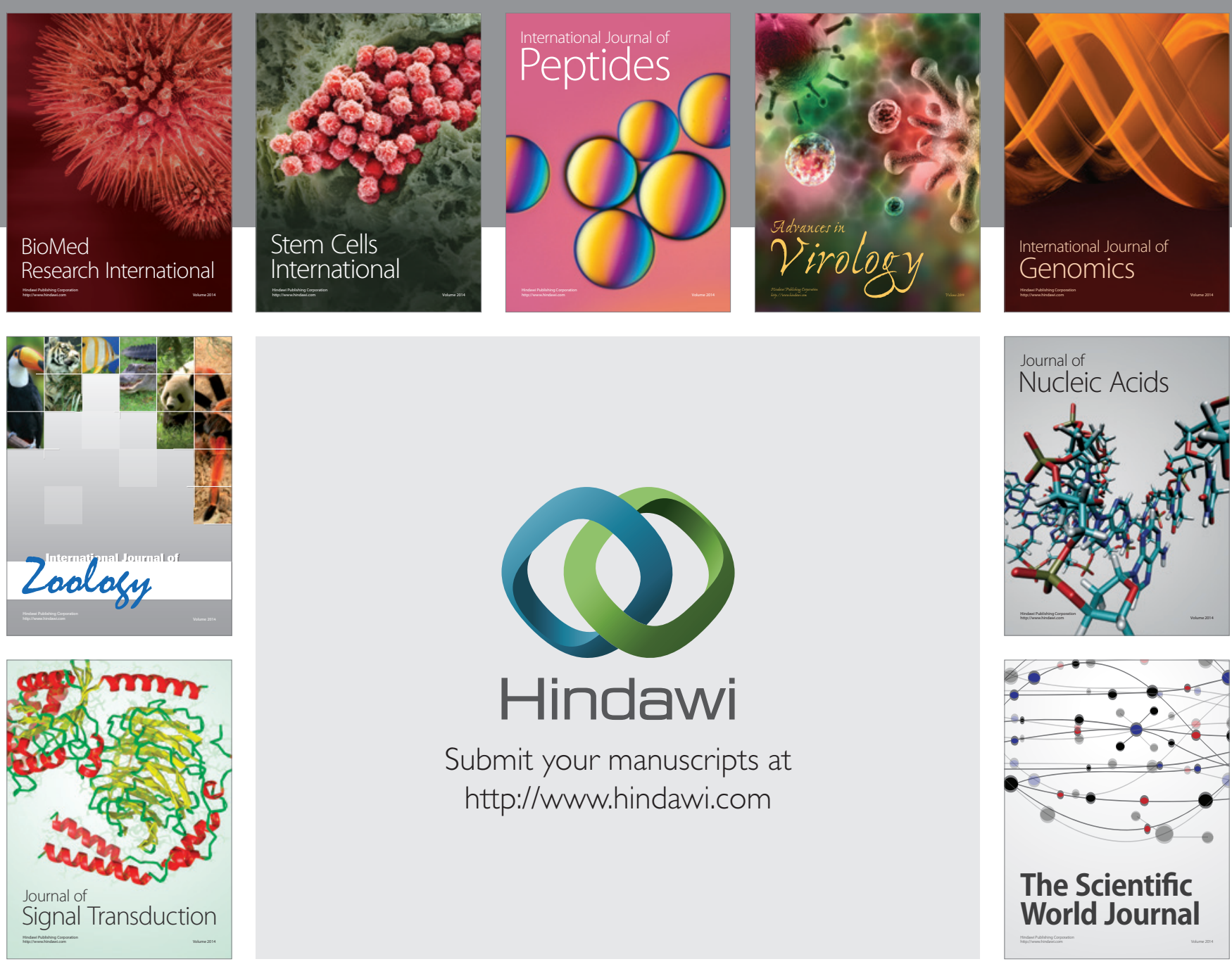

Submit your manuscripts at

http://www.hindawi.com
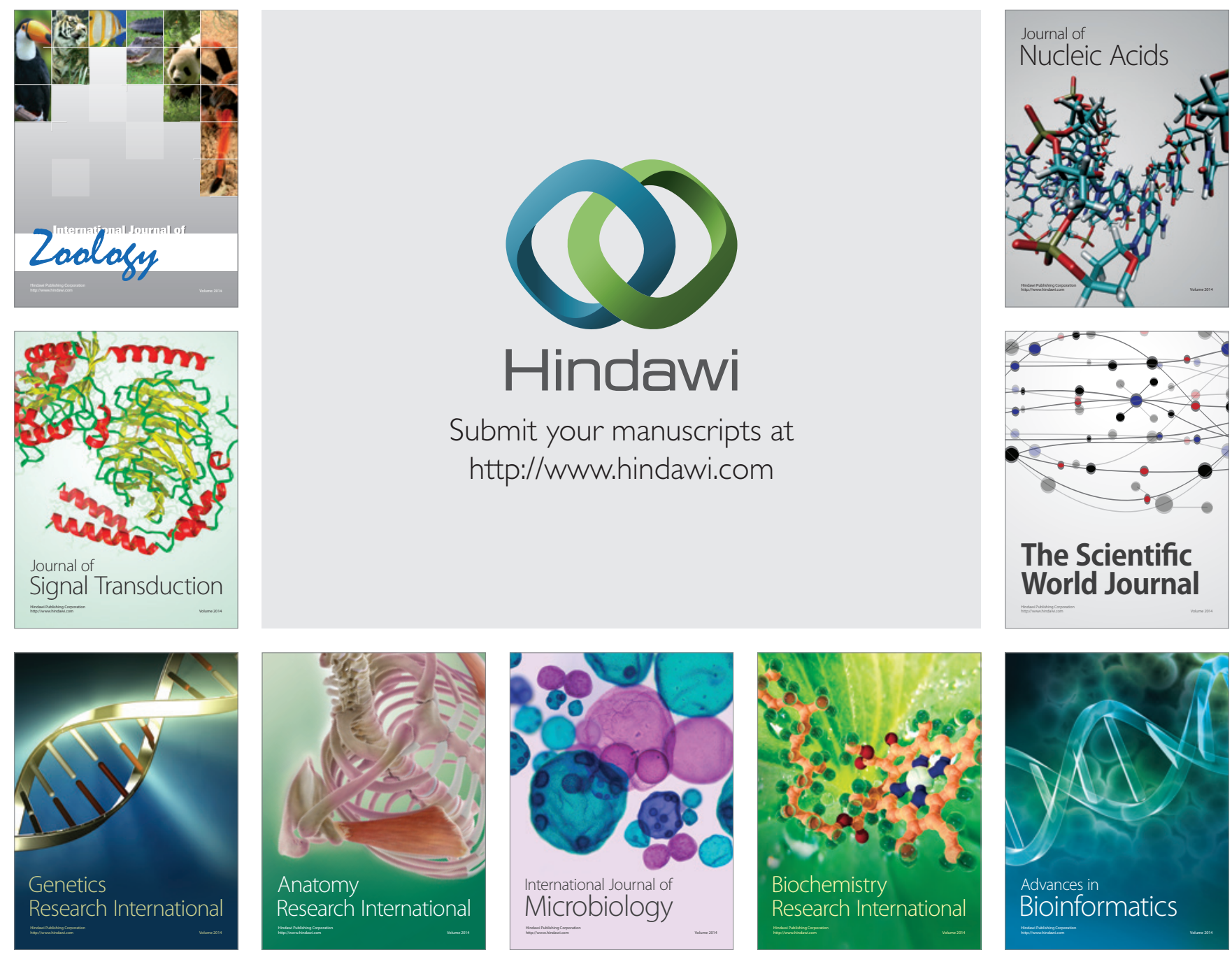

The Scientific World Journal
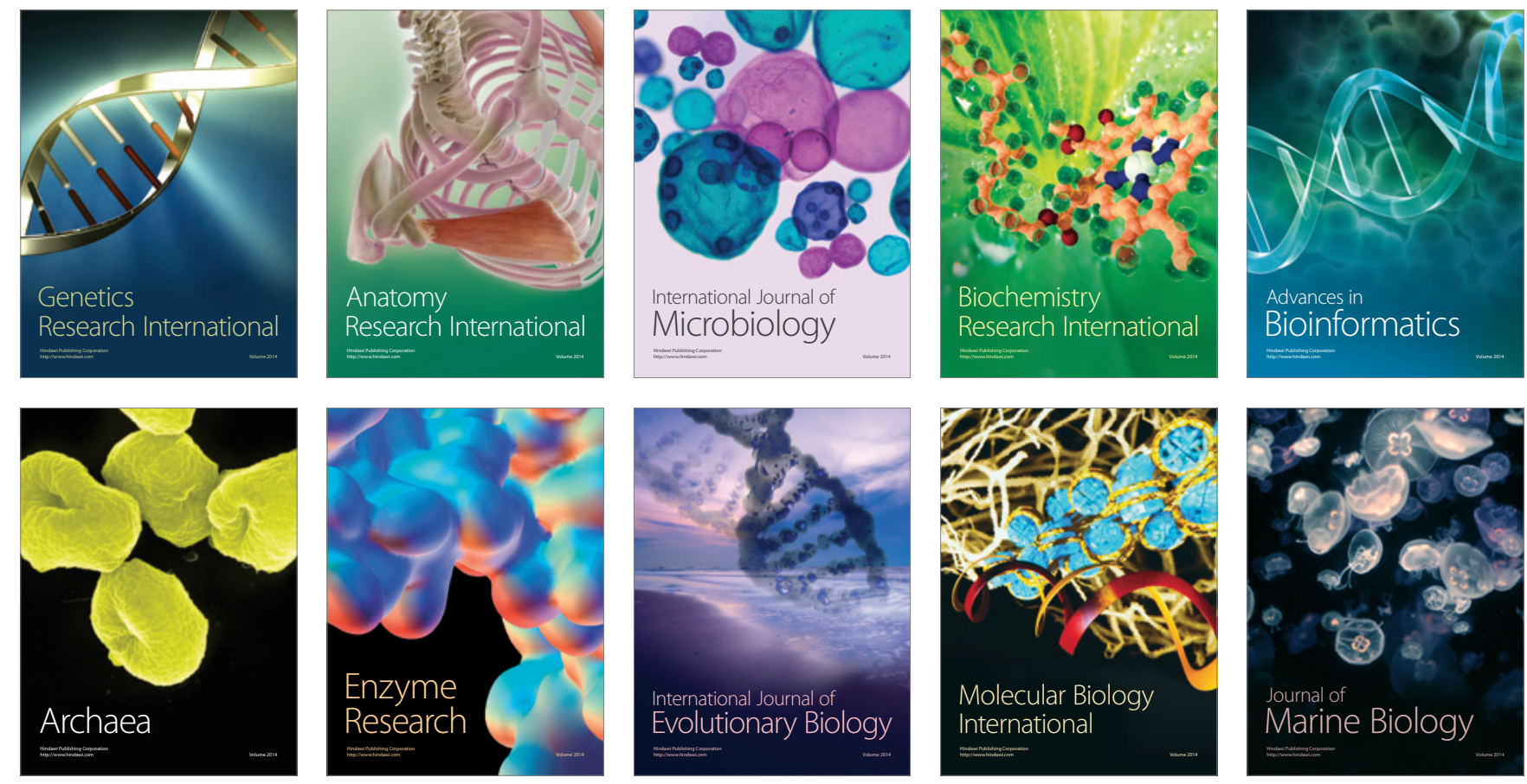